\title{
ABİDA 277. MADDE UYARINCA HUKUKA AYKIRILIK DEF'I
}

\author{
Mustafa T. KARAYİĞíT* \\ Barış HOCAOĞLU**
}

\section{$\ddot{\boldsymbol{O}} z$}

AB tasarruflarinin yargisal denetimi iptal veya ihmal davasi yoluyla doğrudan yargl yollarlyla olabildiği gibi, ön karar usulü ve hukuka aykırllık def'i gibi dolayl yargl yollarlyla da mümkündür. ABIDA 277. maddede düzenlenen hukuka aykırılık def'i, genel nitelikli ana tasarruflara ilişkin zamanaşımı süresine tabi olmaksızın AB yargısı önünde yargısal korunma imkanı sağlamaktadır. Bu itibarla Andlaşma'nın başka bir hükmüne istinaden doğrudan yargı yollarıyla AB yargısı önünde açılan derdest davalarda ileri sürülebilen hukuka aykırılık def'i doğrudan yargı yollarına alternatif veya onları tamamlayan ve onlara bağlı bir yargl yolu olarak yargısal korunma sisteminin etkili tam bir koruma temin etmesinde ön karar usulü yanında önemli bir işlev görmektedir.

Anahtar Kelimeler: hukuka aykırllık def'i, iptal davası, ön karar usulü, dolayll yargl yolu, hukukilik denetimi, etkili yargisal korunma.

\section{THE PLEA OF ILLEGALITY UNDER ARTICLE 277 TFEU}

\section{Abstract}

Judicial review of EU acts can be through either/both direct actions such as actions for annulment and for failure to act or/and indirect actions such as the preliminary ruling procedure and the plea of illegality. The plea of illegality enshrined in Article 277 TFEU provides judicial protection against EU acts of general application before the CJEU notwithstanding the expiry of the period laid down in Article 263 TFEU. In that regard the plea of illegality, which could be invoked before the CJEU in the pending cases brought within the

* Prof. Dr., Marmara Üniversitesi Avrupa Araştırmaları Enstitüsü Avrupa Hukuku Anabilim Dal1, e-posta: mtkarayigit@marmara.edu.tr.

** Avukat İstanbul Barosu, Yüksek Lisans Öğrencisi Marmara Üniversitesi Avrupa Araştırmaları Enstitüsü Avrupa Hukuku Anabilimdalı, e-posta: baris@sebalegal.com. 
context of direct actions articulated in the TFEU, has a significant function alongside the preliminary ruling procedure either as an alternative or a complementary remedy to those direct actions in the provision of complete effective judicial protection.

Keywords: the plea of illegality; the action for annulment, the preliminary ruling procedure, incidental review, legality review, effective judicial protection.

\section{Giriş}

Avrupa Birliği (AB) tasarrufları aleyhine iptal davası açma süresi geçirildiğinde, bu tasarruflar hukuka aykırılıkla malul de olsalar, yok hükmünde tasarruf teşkil etmiyorlarsa eğer, ilgililer açısından aleyhlerine iptal davası çerçevesinde doğrudan yargısal yollarla hukukilik denetimi yapılma imkanı kalmamaktadır. Söz konusu zaman aşımı süresinin geçirilmesine rağmen hukuka aykırılık def'i ve ön karar usulü çerçevesindeki dolaylı yargısal yollar itibariyle bu tasarruflara ilişkin yargısal denetim imkanı ne kadar mümkündür veya tersinden ifadeyle iptal davası açma süresi geçirilmiş tasarruflar kimler için kesinlik niteliği taşıyacaktır? ABAD (Avrupa Birliği Adalet Divanı) iptal davası ehliyetine sahip olan veya davayı açmış olsaydı şüphe gerektirmeyecek düzeyde buna sahip olabilecek olan davacılara bu imkanı tanımakta mıdır ve tanıyorsa bunun gerekçeleri nelerdir? Yani hukuki kesinlik ilkesine istisna oluşturabilecek şekilde hangi ilkeler temelinde nasıl gerekçeler ileri sürülebilir?

Dolaylı yarg1 yollarından hukuka aykırılık def'ini düzenleyen ABIDA (Avrupa Birliği'nin İşleyişine Dair Andlaşma) 277. maddenin metnine göre, 263. maddenin 6. paragrafinda öngörülen sürenin sona ermesine rağmen, Birliğin bir organ veya kurumu tarafindan kabul edilmiş genel uygulama alanına sahip bir tasarrufun söz konusu olduğu bir davada, taraflardan biri, Avrupa Birliği Adalet Divanı önünde bu tasarrufun uygulanamaz olduğunu ileri sürmek için, 263. maddenin 2. paragrafında belirtilen gerekçelere dayanabilir.

$\mathrm{ABAD}, \mathrm{AB}$ tasarruflarının yargısal denetiminde münhasır yetkiye sahiptir. $\mathrm{Bu}$ durum, hem $\mathrm{AB}$ hukukunun bütün $\mathrm{AB}$ hukuk düzeninde yeknesak uygulanmasının, $\mathrm{AB}$ hukuk düzeninin kendi birliği ile hukuki kesinlik ilkesinin, hem de Andlaşmalar tarafindan kurulan yargısal korunma sisteminin tutarlılığının bir gereğidir. (Dava C-314/85, Foto-Frost) ABAD, bir yandan ABIDA 263. maddede düzenlenen iptal davas1, diğer yandan da ABIDA 267. maddede düzenlenen ön karar usulü ve ABİDA 277. maddede düzenlenen hukuka aykırılık def'i ile Andlaşma'nın, AB organ ve kurumlarının tasarruflarının AB yargısı tarafindan hukukilik denetiminin yapılabilmesi için tam bir hukuki çareler ve yargı yolları sistemi kurduğunu ifade etmektedir. (Dava C-294/83 Les Verts, para. 23; Dava C-50/00 P UPA, para. 40) Diğer bir ifadeyle soyut norm denetimi sağlayan iptal davası ile somut norm denetimi 
sağlayan ön karar usulü ve hukuka aykırılık def'i farklı boyutları itibariyle AB tasarruflarının hukukilik denetiminin önemli sac ayaklarıdır. ABIDA 277. maddede düzenlenen ve dolaylı yargı yollarından birisini teşkil eden hukuka aykırılık def'i, gerek ABIDA 263. maddede düzenlenen iptal davası başvurusu yapma imkânı olmayanlar (imtiyazsız davacılar) için alternatif, (Kaczorowska, 2013:445) gerekse iptal davası başvurusu ehliyetine sahip (imtiyazlı veya yarı imtiyazlı davacılar) olmasına rağmen belirli nedenlerle 2 aylık zamanaşımı süresi içerisinde dava açmayanlar için tamamlayıcı mahiyette bir yarg1 yolu teşkil etmektedir. İptal davasının imtiyazsız davacılar olarak gerçek ve tüzel kişiler için doğrudan ve bireysel ilgi şartlarının ispatının zorluğu nedeniyle kısıtlılığı dikkate alındığında, hukuka aykırılık def'i özellikle bu tür davacılar açısından, ön karar usulü kadar olmasa da, "hayat kurtarıcı" bir yargı yolu olarak karşımıza çıkmaktadır.

ABIDA 277. maddede belirtilen prosedürün başlatılmasının yasal temeli, yasa koyucunun atıf yaptığı ABİDA 263. madde ile aynıdır. Bu çerçevede ABIDA 277. maddeye göre, başvurunun gerekçeleri, ABIDA 263. maddede düzenlenen dört yasal zemine dayanabilir: (i) yetkisizlik, (ii) asli bir usul şartının ihlali, (iii) Andlaşmalar'ın veya onların uygulanmasına ilişkin herhangi bir hukuk kuralının ihlali ve (iv) gücün kötüye kullanılması.

Makale, öncelikle, ABİDA 277. madde ve ABAD içtihatları 1şı̆̆ında, ABAD tarafindan hukukun genel ilkesinin bir ifadesi olarak tarif edilen (Dava C-92/78 Simmenthal, para 39; Dava C-262/80 Andersen, para. 6.) hukuka aykırılık def'ini inceleyecektir. Bu çerçevede, hukuka aykırılık def'ine konu tasarruflar, hukuka aykırılık def'inin ileri sürülebilme koşulları, dolaylı bir yarg1 yolu olması hasebiyle hukuka aykırılık def'inin ileri sürülebileceği yarg1 yolları veya usulleri, def'i ileri sürebilecek olanlar ve hukuka aykırılık def'inin hukuki sonuçları sırasıyla incelenecektir. Makalenin ana teması hukuka aykırılık def'inin bir yargı yolu olarak yargısal korunma ilkesi açısından etkililiği analizidir. Bilindiği üzere etkili yargısal korunma ilkesi hem Avrupa İnsan Hakları Sözleşmesi (AİHS) 6. ve 13. maddelerinde, hem de Avrupa Birliği Temel Haklar Şartı 47. maddede düzenlenmiş hem AB hukukunun birincil hukukunun doğrudan kaynağı olarak Kurucu Andlaşmaları ile aynı statüdeki Şart, hem AB Andlaşması 6(3). maddenin AİHS'e doğrudan atfi, hem de üye devletlerin akdettiği temel haklara ilişkin anlaşmaların $A B$ hukukunun genel ilkelerinin parçasını teşkil etmesi itibariyle hukuki güvence altına alınmış kuvvetli bağlayıcılığa sahip bir ilkedir. Bu ilke ayrıca $A B$ hukuk düzeninin meşruiyetinin en temel dayanak noktalarından birini teşkil etmektedir.

\section{Hukuka Aykırılık Def'ine Konu Tasarruflar}

Öncelikle, AB birincil hukuku ABAD'ın yargısal denetimi dışında olduğu için, hukuka aykırılık def'i ileri sürülebilecek tasarrufların $A B$ organları ve 
kurumlarının tasarrufları olması ve bu tasarrufların da yargısal denetime tabi nitelikte olması gerekir. İkinci nokta itibariyle bir yandan ortak dış ve güvenlik politikası çerçevesinde kabul edilen bazı tasarrufların yargısal denetime tabi olmadığ 1 , diğer yandan da yargısal denetime tabi $\mathrm{AB}$ tasarruflarının denetime tabi olduğu müktesebat açısından doğrudan etkili olmayan $\mathrm{AB}$ tarafindan akdedilen DTÖ Anlaşması gibi bazı uluslararası anlaşmaların hükümleri çerçevesinde, her ne kadar Fediol ve Nakajima içtihadı bazı istisnalar getirse de (Dava C-70/87 Fediol; Dava C-69/89 Nakajima), yargisal denetime tabi tutulamayacağının gözden kaçırılmaması gerekliliğinin burada belirtilmesi gerekir.

Yargısal denetime tabi $\mathrm{AB}$ tasarrufları çerçevesinde ise hukuka aykırılık def'i, genel uygulama alanına sahip tasarruflara ilişkin ileri sürülebilir. (Craig and de Búrca, 2011:515) Bu sebeple birel işlemler aleyhine hukuka aykırılık def'i söz konusu olamaz. Bu çerçevede ABAD'ın bakış açısına göre, tasarrufun şeklinin, örneğin tüzük, yönerge veya karar olmasının, bir önemi yoktur ve genel uygulama alanına sahip tasarruf noktasında tasarrufun özünün dikkate alınması gerekmektedir. (Dava C-92/78 Simmenthal) Hukuka aykırılık def'i Roma Andlaşması metnine istinaden önceleri yalnızca Konsey ve Komisyon tarafından kabul edilen tüzükler ile sınırlı iken, bu kapsam ABAD'ın içtihatları yoluyla objektif olarak belirlenen durumlara uygulanabilen ve soyut olarak tanımlanabilen kişi kategorileri açısından hukuki etki doğuran bütün genel uygulama kapasitesi olan tasarrufları içine alacak şekilde genişletilmiştir. ( Dava C-92/78 Simmenthal; Dava T-764/16 Jörn Paulini, para. 32; Kaczorowska,2013:446) Yani ABAD hukuka aykırılık def'ini düzenleyen maddeyi Lizbon Andlaşması (ABIDA) öncesinde bu maddede geçen tüzük kavramını geniş yorumlamak suretiyle, tüzük şeklinde olmasalar da esasta benzer etkilere sahip ve iptal davası çerçevesinde gerçek ve tüzel kişiler tarafından aleyhlerine dava açılamayacak nitelikte genel uygulanma doğasına sahip tasarrufları da kapsayacak şekilde değerlendirmiştir. (Dava C-92/78 Simmenthal, para. 40-41; Birleşik Davalar T-6/92 and T-52/92 Reinarz, para. 56; Birleşik Davalar T-222/99, T-327/99 and T-329/99 Martinez, para. 134) Bu noktada belirtilmesi gereken bir husus olarak, aşağıda işlenecek olduğu üzere, ön karar usulü bağlamında hukuka aykırılık def'inin mümkün olmaması ve yönergelerin her zaman üye devletleri muhatap alan tasarruflar olmaları nedeniyle bu tasarrufların her ne kadar yargısal denetiminin geçerlilik amacıyla ön karar usulü çerçevesinde başvurular yoluyla sağlanması makul olarak beklenebilir bir karakteristik olsa da, bu durum hukuka aykırılık def'ine konu olamayacakları anlamına da gelmemektedir. (Dava C-86/03 Greece v Commission, para. 86.) Genel olarak Lizbon Andlaşması da, hukuka aykırılık def'inin genel uygulama kapasitesine sahip bütün tasarrufları konu edecek şekilde gelişen bu yerleşik içtihadı kodifiye etmiştir. Ayrıca Lizbon Andlaşması'nda, yargısal denetime tabi AB tasarruflarının sadece organ 
tasarruflarından müteşekkil olmaması ve dolayısıyla bütün $\mathrm{AB}$ kurumlarının tasarruflarını da içermesine yönelik içtihadı da ABIDA 277. maddeye AB kurum, ofis ve ajanslarının genel uygulanma kapasitesi olan tasarruflarının da eklenmesi suretiyle kodifiye edilmiş olmaktadır. (Dava T-411/06 Sogelma, para. 37)

Diğer bir nokta olarak ikincil hukuki etkiler doğuran, yani kişilerin hukuki durumunu, yani hak ve yükümlülüklerinin bütününü etkilemeyen, fakat hukuken bağlayıcı birincil hukuki etkiler doğuran bir tasarrufa hukuki dayanak teşkil etmek suretiyle hukuki durumunu etkileyen tasarrufların, doğrudan yargısal yollarla değil de, ön karar usulü veya hukuka aykırılık def'i çerçevesinde, yani dolaylı yargısal yollarla, denetiminin yapılabileceği de literatürde ifade edilmektedir. Bu görüş çerçevesinde üçüncü kişiler için ancak nihai tasarruf marifetiyle bağlayıcı hukuki etkiler doğuran tasarruflar (soft law örnekleri), kendileri bağlayıcı hukuki etki doğurmasalar da, birincil hukuki etkiler doğuran bağlayıcı tasarrufları belirlemekte ve onlara olanak sağlamaktadırlar. (Türk and Xanthoulis, 2019; Xanthoulis, 2019) Bu çerçevede tavsiyelerin, (Dava C-322/88 Grimaldi) Komisyon'un tebliğlerinin (communications), (Birleşik Davalar C-189/02 P, C-202/02 P, C-205/02 P to C-208/02 P and C-213/02 P Dansk Rørindustri, paras. 209-212; Dava T-376/10 Robinetteria, paras. 49-53) rehber ilkelerin (guidelines), (Dava T-64/02 Heubach, para. 35) her ne kadar bu tasarruflar bağlayıcı hukuk kuralları olarak addedilmese de, idarenin somut durumlarda gerekçe göstermeden sarf-1 nazar edemeyeceği uygulama esasları veya ilkeleri olarak görüldüğünden, dava konusu tasarrufla doğrudan hukuki bağlantısının olması durumunda bu tür tasarruflara ilişkin de hukuka aykırılık def'i ileri sürülebileceği içtihatta kabul edilmektedir. Ancak şunun da bilinmesi gerekir ki, bazı davalarda ABAD'ın idare için bağlayıcı olmadığı gerekçesiyle bu türdeki bazı tasarrufları hukuka aykırılık def'inin konusu yapmadığı da vakidir. (Dava T-373/04 Guggenheim, para. 35.) Bu noktada belki de ABAD'ın bu imkanı tanımasının altında yatan kriterin, her ne kadar bağlayıcı olmasa da söz konusu organın bu tasarrufu dikkate alma ve tasarrufuna hukuki dayanak yapma iradesi göstermesi olduğu iddia edilebilir.

Gerçek ve tüzel kişiler için doğrudan ve dolaylı yargı yolları arasındaki ayrım genel düzenleyici tasarruflar ile birel tasarruflar arası ayrıma dayanmaktadır. İmtiyazlı davacılar için ise hukuka aykırılık def'ine tanınan işlev aslen bu ayrımın temelini şekillendirecektir. Ama bu ikinci kategorideki ayrım yine de hukuka aykırılık def'i çerçevesinde imtiyazlı davacılar bağlamında yargısal denetime tabi tasarrufların niteliğinin genel uygulaması olan tasarruf kategorilerinden hangisini içerecek şekilde etkileme kapasitesi olduğunu belirleyecektir. Bilindiği üzere iptal davası çerçevesinde imtiyazlı davacıların $\mathrm{AB}$ tasarrufları aleyhine dava açabilmeleri için her hangi bir hukuki 
menfaat ispatlama gereği ve dolayısıyla bir bariyer söz konusu değildir. Oysaki imtiyazsız davacılar açısından doğrudan ve bireysel ilgi ile hukuki menfaat ispatlama zorunluluğu bulunduğu, özellikle de ABAD tarafindan bireysel ilgi olabildiğine kısıtlı yorumlandığı için, (Dava C-25/62 Plaumann) iptal davası bu tür davacılar için istisnai bir yargı yolu teşkil etmektedir. Bu çerçevede ikinci kategori, imtiyazsız davacılardan farklılık arz edecek şekilde, imtiyazlı davacılar açısından doğrudan ve dolaylı yargı yollarıyla denetime tabi tasarruf ayrımını değil, dolaylı yarg1 yollarıyla denetime tabi tasarrufların kapsamını belirleyici niteliktedir. Başka bir ifadeyle hangi tasarrufların hukuka aykırılık def'inde yargısal denetime tabi olduğu kadar, kimler bağlamında bu denetimin mümkün olduğu da bu tasarrufların kapsamını belirleyici mahiyettedir. $\mathrm{Bu}$ itibarla, hukuka aykırılık def'ine tabi tasarruflar, ilkesel olarak genel uygulama kapasitesi olan tasarruflar olsa da, bu tasarrufların kapsamı hukuka aykırılık def'ini ileri sürebilme koşulları, def'i ileri sürebilme kapasitesi olanlar ve bunun hangi gerekçeye dayandığı, def'in ileri sürülebileceği dava ve usuller ile birlikte değerlendirilebilecek bir meseledir.

\section{Hukuka Aykırılık Def'inin İleri Sürülebilme Koşulları}

ABAD tarafından da vurgulandığı üzere ABİDA 277. madde başvuruculara bağımsız bir itiraz hakkı doğurmamaktadır. (Birleşik Davalar C-87, C-130/77, C-22/83, C-9 and C-10/84 Salerno, para. 36; Dava C-239/99 Nachi Europe, para. 33; Lenaerts, Maselis and Gutman, 2015:441) Bu itibarla hukuka aykırılık def'i, ilgili kişiye genel uygulaması olan hukuka aykırı bir tasarrufun uygulanmasına karşı bir koruma olanağı vermek (Dava T-787/14 P Cerafogli, para. 45; Dava T-455/16 P González, para. 34) üzere, ancak Andlaşma'nın başka bir hükmü kapsamındaki bir yargı yoluyla açılmış derdest bir davada ABAD önünde ileri sürülebilir. (Birleşik Davalar C-31 and 33/62 Lütticke) $\mathrm{Bu}$ noktada yetki ve görev bölüşümü çerçevesinde davanın Divan veya Genel Mahkeme önünde açılması gerekliliği, hukuka aykırılık def'inin o mahkeme önünde ileri sürülmesini gerektirecektir. Bu itibarla, hukuka aykırılık def'ine yalnızca fer'i bir itiraz olarak başvurulabilir. (Kaczorowska, 2013:445) Tersinden bakılacak olursa, hukuka aykırılık def'i bağımsız bir yargı yolu olmadığından ve dolaylı bir yargı yolu olması hasebiyle arızi ve bağlı bir def'i olarak ileri sürülebileceğinden dolayı, Andlaşma'nın başka bir hükmüne istinaden açılmış bağımsız bir davaya ihtiyaç duyar. (Dava T-369/03 Arizona Chemical, para. 129.) Bu açıdan, hukuka aykırılık def'inin ileri sürülebilmesi, Andlaşma'nın başka bir hükmüne istinaden ABAD önünde bağımsız olarak açılan davanın kabul edilmesine bağlı hale gelmektedir. (Birleşik Davalar T54/00 and T-73/00 Federación de Cofradias, para. 82; Dava C-368/05 P Polyelectrolyte Producers Group, para. 72)

Hukuka aykırılık def'ini ileri sürebilmek için ayrıca davanın tarafının bir hukuki yararının bulunması ve itirazın ileri sürene bir avantaj doğuracak 
nitelikte olmas1 gerekmektedir. (Dava C-174/99 P, Pierre Richard, para. 33; Dava T-135/05 Campoli, para. 132) İlaveten, hukuka aykırılık def'i ancak davacı açısından dava dilekçesinde, davalı açısından da cevap dilekçesinde ileri sürülebilir. $\mathrm{Bu}$ itibarla hukuka aykırılık def'inin iddia veya savunmayı genişletme mahiyetinde olacak şekilde, yani davacı için başvuruda dava dilekçesinde ve davalı için de cevap dilekçesinde değil de replik ve düplik dilekçelerinde ileri sürülmesi imkanı yoktur. (Birleşik Davalar C-87/77, C130/77, C-22/83, C-9/84 and C-10/84 Salerno, para. 37; Birleşik Davalar T-134/03 and T-135/03 Common Market Fertilizers, para. 51) Hukuka aykırılık def'i davanın açıldığ 1 sırada veya davalı açısından da savunmada, sarih olarak ABIDA 277. maddeye atıfta bulunularak veya maddeye atıfta bulunulmasa da hukuka aykırılığın yeterli açıklıkta sebepleri belirtilerek hukuka aykırılığı iddia edilmek suretiyle zımni mahiyette ileri sürülmesi gerekir. (Dava T-120/99 OHIM, para. 22; Dava C-86/03 Hellenic Republic v Commission, paras. 82-85)

Öte yandan, ABAD'a göre ABİDA 277. madde çerçevesinde hukuka aykırılık def'inin konusu tasarruf, dava konusu uyuşmazlığa doğrudan veya dolaylı olarak uygulanabilir olmalı ve uyuşmazlığa konu bireysel karar ile söz konusu genel uygulama alanına sahip tasarruf arasında doğrudan bir hukuki bağlantı (Birleşik Davalar C-140, 146, 221 and C-226/82 Thyssen, para. 20; Birleşik Davalar T-93/00 and T-46/01 Alessandrini, para. 77; Birleşik Davalar T-222/99, T-327/99 and T-329/99 Martinez, para. 136; Dava T-140/12 Teva Pharma, para. 51) veya yeterince alaka (Dava C-32/65 Italy v Council and Commission) bulunmalıdır. Yani davanın konusu tasarrufun hukuki dayanağını teşkil etmek (Dava C-92/78 Simmenthal, para. 39; Birleşik Davalar C-140, 146, 221 and C-226/82 Thyssen Aktiengesellschaft, para. 20; Dava T-120/99 OHIM, paras. 25, 33.) veya bu tasarrufun kabulüyle alakalı tasarruf olmak (Dava T146/96 De Abreu v Court of Justice EU:T:1998:50, para. 27; Birleşik Davalar T-222/99, T-327/99 and T-329/99 Jean-Claude Martinez and others $\mathrm{V}$ Commission EU:T:2001:242, para. 135) hukuka aykırılı def'inin ileri sürülebilmesini sağlamaktadır. Daha genel ifadeyle, genel uygulanma kapasitesi olan tasarrufun davadaki meseleye uygulanabilir olmas1 gerekmektedir. (Dava C-32/65 Italy v Council and Commission, para. 6; Dava T-58/01 Solvay, para. 148) Tahmin edilebileceği üzere, bu şart itibariyle ABAD genel tasarruf ile uyuşmazlık konusu tasarruf arasında bağlantı bulunmadığ 1 durumlarda, örneğin tasarruf ile hukukiliğine etki edebilecek ölçüde yeterli bağı bulunmadığ gerekçesiyle, hukuka aykırılık def'ini reddetmektedir. (Dava C-32/65 Italy v Council and Commission) Bu itibarla, karşımıza aynı anda yürütülen iki süreç çıkmaktadır: uyuşmazlık konusu olan tasarrufa veya ihmale karşı doğrudan başlatılan asli dava ve tasarrufun dayandığı ve onunla yeterli hukuki bağının olduğu ana tasarrufa karşı hukuka aykırılık def'i yolu ile dolaylı olarak başvurulan fer'i itiraz. (Hukuk Sözcüsü Slynn'ın Görüşü, Dava C-181/85 France $v$ Commission EU:C:1986:491) Bu noktada şu nokta gözden uzak 
tutulmamalıdır: hukuka aykırılık def'i genel uygulaması olan tasarrufun kendisine yönelik ve kendisine özgü bir hukukilik denetimi değildir. Bu itibarla uygulayıcı tasarrufun kendisine özgü noksanlıkları nedeniyle iptal edilmesi durumunda ABAD hukuka aykırılık def'ini incelemeyi bile gereksiz bulmaktadir. (Dava C-91/05 Commission v Council, para. 111) Bu itibarla hukuka aykırılık def' inde $\mathrm{AB}$ yargısının odak noktası ve meselesi uyuşmazlığın çözümünde gerekli, yeterli ve kaçınılmaz olandan ötesi değildir. (Dava T-140/12 Teva Pharma, para. 51; Dava T-764/16 Paulini, para. 29; Dava T-788/16 Dominique de Geoffroy, para. 80)

AB hukukunda dolaylı yargı yolları genel olarak ve hukuka aykırılık def'i de özel olarak her hangi bir zaman aşımına uğramaya tabi değildir ve koşullarının karşılanması durumunda her zaman ileri sürülebilir. Ancak ABIDA 263. maddede düzenlenen zaman aşımı süresinin olmaması ise, hukuka aykırılık def'inin iptal davasına ilişkin koşulların etrafından dolaşmak için kullanılabileceği anlamına da gelmemektedir. (Dava C-156/77 Commission v Belgium, paras. 24-25)

\section{Hukuka Aykırılık Def'inin İleri Sürülebileceği Dava ve Prosedürler}

Hukuka aykırılık def'inin ileri sürülebileceği davalar arasında ABIDDA 277. maddenin de atıfta bulunduğu ve en çok karşılaşılan nitelikteki iptal davası (Dava T-120/99 Christina Kik, para. 20; Dava C-86/03 Hellenic Republic v Commission, para. 81; Dava T-140/12 Teva Pharma, para. 51) ile ABIDA 270. madde çerçevesindeki personel davası (Dava C-20/71 Sabbatini v Parliament) öne çıkmaktadır. (Türk, 2009:211) Ayrıca ABIDA 258-260. maddelerde düzenlenen ihlal davası (Dava C-116/82 Commission v Germany; Dava C475/01 Commission v Greece) ve ABIDA 268. ve 340. maddelerde düzenlenen tazminat davası da (Dava T-369/03 Arizona Chemical, para. 129; Dava T271/04 Citymo, paras. 68, 76, 118) hukuka aykırılık def'i ileri sürülebilecek davalar olarak siralanabilir.

Zaten ABIDA 277. maddenin lafzının da atfettiği iptal davasının hukuka aykırılık def'ine en fazla konu olan dava olması hasebiyle ayrıca ele alınması gerek bile yoktur. Tazminat davası da ABAD tarafından teyit edilmiştir. Ancak etkili yargısal korunma ilkesi açısından, $A B$ 'nin sözleşme dişı sorumluluğu çerçevesindeki ABIDA 268. ve 340. maddeler bağlamında tazminat davalarının aslen doğrudan hukukilik denetimine matuf olmaması ve bunun ancak dolaylı olarak gerçekleştirildiği davalar teşkil etmesi hasebiyle bazı hukukçular tarafindan bu davalarda hukuka aykırılık def'inin sinırlı bir faydasının olacağının savunulduğunun bilinmesi gerekir. (Lenaerts, Maselis and Gutman, 2015:453)

İhmal davası çerçevesinde hukuka aykırılık def'inin ileri sürülebilmesi olasılığı tarafımıza sadece davalı taraf açısından mümkün gözükmektedir. 
Çünkü davacının kabulünde ihmali olduğu gerekçesiyle bir organ veya kuruma karşı açtı̆̆ 1 ihmal davasında, zaten ihmali söz konusu olan tasarrufun kaynağ olan genel nitelikli ana tasarrufun hukuka aykırılığını iddia etmesi mantıki bir argüman teşkil etmez. Davalı açısından ise ihmal davası, ancak davacı tarafından yapılan idari başvuru talebine karşı bir tutum belirlememesi durumunda söz konusu olabilecektir. Yani söz konusu organ veya kurumun, ana düzenlemenin gerektirdiği tasarrufta bulunmama gerekçesini bu tasarrufun hukuka aykırı olduğuna dayandırarak talebi reddetmesi durumunda zaten ancak iptal davası açılabilecektir. (Hukuk Sözcüsü Lenz'in Görüşü, Dava C-13/83 Parliament v Council EU:C:1985:53; Schermers and Waelbroeck, 2001:482) $\mathrm{Bu}$ itibarla sadece davalı organ veya kurumun tutum belirlememesi nedeniyle aleyhlerine açılan ihmal davasında davalı olarak söz konusu tasarrufa ilişkin hukuka aykırılık def'i tarafımıza mümkün olarak görünmektedir. Ancak bu durumda da aynen ihlal davası çerçevesinde üye devlet mazeretlerine uygulanan içtihada paralel olarak, bu imkanın iptal davası başvuru süresinin geçmesinden sonra ortaya çıkan hukuka aykırılık durumlarına hasredilmesi, $\mathrm{AB}$ hukukunun ihmal ve ihlalin kim tarafından yapıldığına bakılmaksızın yeknesak uygulanmasının tutarlı şekilde sağlanması adına önem arz ettiğinin de belirtilmesi gerekmektedir. Bu çerçevede yargısal korunma ilkesi açısından ihmal davasının gerçek ve tüzel kişiler açısından bir etkililiği söz konusu gözükmemektedir. İhmal davası çerçevesinde hukuka aykırılık def'i sadece idari başvuruya karşı bir tutum belirlememiş ama aleyhine ihmal davası açıldıktan sonra ihmalinde genel uygulama kabiliyetindeki tasarrufun hukuka aykırılığını iddia eden bir organ için geçerliliği var gibi gözükmektedir.

Ön karar usulü çerçevesinde hukuka aykırılık def'i ileri sürülemez. (Dava C239/99 Nachi Europe, para. 34) Bunun üç gerekçesi (Lenaerts, Maselis and Gutman, 2015:45) vardır: Birincisi ABAD tarafindan da belirtildiği üzere, hukuka aykırılık def'inin Andlaşma'nın başka bir hükmü kapsamındaki bir yarg1 yoluyla açılmış derdest bir davada ancak ABAD önünde ileri sürülebilecek olmasıdır. (Birleşik Davalar C-31 and C-33/62 Lütticke) Bu bağlamda ön karar usulünün ulusal mahkemeler nezdinde açılan davalarda yararlanılacak bir usul olması hasebiyle, (Birleşik Davalar C-31 and C-33/62 Lütticke; Dava C-44/65 Singer; Dava C-239/99 Nachi Europe, para. 34) yani adem-i merkezi bir denetim mekanizması olarak, hukuka aykırılık def'i ulusal mahkeme önünde ileri sürülemeyecektir. İkincisi ise ön karar usulü AB yargıs1 önünde başvurulabilecek doğrudan yarg1 yolu olma hüviyetinden yoksundur. Yukarıda da belirtildiği üzere hukuka aykırılık def'i ilk merhalede ileri sürülmelidir; iddia ve savunmanın genişletilmesi mahiyetinde ileri sürülemez. $\mathrm{Bu}$ özelliği de ön karar usulü çerçevesinde ileri sürülmesine engel olacaktır. Üçüncüsü ise, hukuka aykırılık def'inin taraflardan biri tarafindan ileri sürülebilmesi gerektiğinden davanın çekişmeli yarg1 teşkil etmesi gerekmektedir. (Dava C-44/65 Singer; Nachi Europe, para. 34; Bebr, 1981:207) 
Bilindiği üzere, ön karar usulü yargıçlar arası diyaloğa dayanan çekişmesiz bir usuldür ve tarafların bu usulde bir dahli söz konusu değildir. Yani ABIDA 267. madde çerçevesinde meseleyi Divan'a havale eden ulusal mahkemenin önündeki davanın tarafları değil, ulusal mahkemenin kendisidir. (Dava C-44/65 Singer) $\mathrm{Bu}$ noktada hukuka aykırılık def'inin tarafların kişisel çıkarlarının korunmasıyla ilgili bir yarg1 yolu, ön karar usulünün ise $\mathrm{AB}$ hukukunun yeknesak yorumlanması ve uygulanması amacını taşıdığı da bir detay olarak ifade edilebilir. (Sinaniotis, 2001) Zaten bu itibarla Divan, ABIDA 277. maddede yer alan genel bir hukuk ilkesi olarak hukuka aykırılık itirazının ulusal tasarrufun temelini oluşturan $\mathrm{AB}$ tasarrufu aleyhine yapılabilmesinin ABIDA 267. maddede düzenlenen ön karar usulüyle gerçekleştirilebileceğini ifade etmektedir. (Dava C-441/05 Roquette Frères, para. 39)

İhlal davalarında üye devletlerin AB tasarrufunun hukuka aykırılığı iddialarına dayanan mazeretlerinin $\mathrm{ABAD}$ nezdinde çok kabul görmediği, ( Dava C-74/91 Commission v Germany, para. 10; Dava C-183/91 Commission v Greece, para. 10; Dava C-404/97 Commission v Portugal, para. 34; Dava C404/00 Commission v Spain, para. 40) bu içtihadına istisna olarak ciddi ve bariz sakatlık taşıması nedeniyle yok hükmünde değerlendirdiği tasarruflara ilişkin mazeretleri kabul ettiği dikkate alınırsa, (Birleşik Davalar C-90/63 and 91/63 Commission v Luxembourg and Belgium; Dava C-226/87 Commission v Greece, paras. 13-14) ihlal davalarında hukuka aykırılık def'inin etkililiğinin sınırlı olacağı öngörülebilir. Bu çerçevede hukuka aykırılık def'ini ileri sürecek üye devletin iki aylık süre içerisinde neden tasarruf aleyhine iptal davası açmadığını da makul gerekçelerle açıklaması gerekecektir. Bu çerçevede hukuka aykırılık def'inin tamamlayıcı boyutta imtiyazlı davacılara ancak kendilerini muhatap almayan ve hukuka aykırılığ 2 aylık sürenin geçmesinden sonra, özellikle de uygulayıcı tasarruflarla, ortaya çıktığı durumlara hasredilmesi ile ihlal davası çerçevesinde hukuka aykırılık def'ini makul gerekçelerle açıklama arasında bir benzerlik göze çarpmaktadır. Bu bağlamda söz konusu sinırlılığın ihlal davasından ziyade hukuka aykırılık def'inin imtiyazlı davacılara ne kadar imkan tanıyan bir yarg1 yolu olduğuna ilişskin, yani iptal davasına alternatif nitelikte mi yoksa tamamlayıcı nitelikte mi bir yargı yolu olduğuna ilişkin, yaklaşımdan kaynaklanacağı da açıktır. Başka bir ifadeyle söz konusu sınırlılık ihlal davasının değil, hukuka aykırılık def'inin doğasından kaynaklanan bir sinırlılık olacaktır.

Genel olarak, ön karar usulü çerçevesinde hukuka aykırılık def'inin mümkün olmadığı, ihmal, ihlal ve tazminat davalarında ise yargısal korunma ilkesi açısından etkililiğine dair sınırlılıklar dikkate alındığında, hukuka aykırılık def'inin iptal ve personel davalarında yargısal korunma ilkesi açısından etkililiğinin bulunacağı kanaatimizce öngörülebilecektir. 


\section{Hukuka Aykırılık Def'ini Kimler İleri Sürebilir?}

Hukuka aykırılık def'ini Andlaşma'nın başka bir hükmüne istinaden açılan davanın her iki tarafı da ileri sürebilir. (Lenaerts, Maselis and Gutman, 2014:450) Bunun yanında, hukuka aykırılık meselesi bir kamu düzeni meselesi olması hasebiyle istisnai olarak, davanın tarafları tarafından ileri sürülmese bile, her ne kadar ABIDA 277. madde lafzındaki def'i veya itiraz kavramı hukuka aykırılık def'inin sadece taraflar tarafindan yararlanılacak bir itiraz mekanizması olarak yapılandırıldığı anlamında yorumlanabilmeye müsait de olsa, hukuka aykırılık meselesi hukukilik, hukuki kesinlik, yargısal koruma ilkeleri ve $\mathrm{AB}$ hukukunun meşruiyeti açısından mahkeme tarafından da re'sen (ex officio) değerlendirmeye alınabilir. (Dava C-14/59 Société des fonderies de Pont-à-Mousson; Dava C-443/05 P Common Market Fertilizers, para. 138; Birleşik Davalar F-69/07 and F-60/08 O v Commission, para. 71; Lenaerts, Maselis and Gutman, 2014:450) ABAD bu noktada tasarrufun hukukiliğine ilişkin şüpheleri izale etmek adına, davanın taraflarından bir talep bulunmamasına rağmen re'sen hukuka aykırılık meselesini dikkate almaktadır. (Dava C-14/59 Société des fonderies de Pont-à-Mousson) Ancak ABAD'1n bu denetimi, hukukilik meselesinin bir kamu düzeni meselesi olduğu durumlara hasrettiğini de belirtmek gerekmektedir. (Birleşik Davalar T-134/03 and T-135/03 Common Market Fertilizers, para. 52)

ABAD'a göre ABIDA 277. madde, her bir tarafa tasarrufa karş1, doğrudan ve bireysel ilgisinin olduğu kararın iptalini sağlama amaciyla, eğer bu taraf ABIDA 263. madde çerçevesinde iptal davası açma ehliyetine sahip değilse, bu kararın hukuki dayanağını oluşturan organların önceki tasarruflarının geçerliliğine itiraz etme hakkı tanıdığı ilkesinin genel bir ifadesini teşkil etmektedir. (Dava C-92/78 Simmenthal, para. 39) ABIDA 277. maddede düzenlenen hukuka aykırılık def'i, aslen iptal davası ehliyeti şartlarını sağlayamayan imtiyazsız davacıların yararlanması amacı ile ortaya çıkmıştır ve bu içtihat da imtiyazsız davacılar açısından katı bir şekilde uygulanmaktadır. (Dava C-188/92 Deggendorf, paras. 24-25; Dava C-241/01 National Farmers' Union, para. 34; Dava C-119/05 Lucchini, para. 54; Bebr, 1981:93) Bu itibarla Andlaşma'da hukuka aykırılık def' i esasen, gerçek ve tüzel kişilerin iptal davası ehliyeti kısıtlılığını telafi edecek bir yarg1 yolu olarak ihdas edilmiştir. Bu nedenle $\mathrm{ABAD}$, uyuşmazlık konusu düzenleme kendilerine tebliğ edilmediği, dolayısıyla bu düzenlemeye karşı iptal davasına başvurulacak süreyi dolduran imtiyazsız başvurucuların alternatif bir yargı yolu olarak düzenlemeyi Divan önüne getirmeleri gerektiği yaklaşımını destekler bir bakış açısına sahiptir. (Shaw, 1993:340) Bu açıdan, imtiyazsız davacılar için hukuka aykırılık def'i adaletin reddinin önlemesi ve genel uygulaması olan tasarrufların dolaylı yargı yoluyla denetiminin süreye tabi olmaksızın sağlanması olarak ortaya çıkmaktadır. (Vogt, 2006) 
Divan'ın Simmenthal'deki (Dava C-92/78 Simmenthal) ABIDA 277. madde düzenlemesinden imtiyazlı davacıların da yararlanabileceği yönündeki hükmü, suyu bulandırmak olarak nitelendirilerek eleştirilmiştir. (Türk, 2009:211) Çünkü düzenleme ilk ortaya çıktığında öğretide hiçbir imtiyazlı başvurucunun hukuka aykırılık def'ini ileri süremeyeceği kanaati hakimdi. Çünkü hukuka aykırılık def'inin sadece dava ehliyeti bulunmadığı için iptal davasına başvuramayan ve dolayısıyla düzenlemeyi doğrudan doğruya uyuşmazlık konusu edemeyen imtiyazsız davacıların haklarını korumak amaciyla ortaya çıktığı düşünülmekteydi. Başka bir ifadeyle, hukuka aykırılık def'inin yalnızca doğrudan yarg1 yolu kapalı olan gerçek ve tüzel kişiler tarafından ileri sürülebileceği ifade edilmekteydi (Hukuk Sözcüsü Jacobs'ın Görüşü, Dava C11/00 Commission v ECB, para. 193) ve bu durum, imtiyazlı davacıların iptal davası için öngörülen hak düşürücü sürenin arkasından dolaşmasının engellenmesi sebebiyle, hukuki belirlilik ilkesine paralel olduğu gerekçesiyle savunulmaktaydı. (Türk, 2009:211) Ancak bazı hukuk sözcülerinin ve hukukçuların bu yaklaşım aleyhinde görüşleri ABAD'ın hukuka aykırılık def'ini ileri sürebilecek tarafları daha geniş yorumlamasına da temel oluşturmuştur. Bu noktada ortaya çıkan temel argüman, bir düzenlemenin hukuka aykırılığının genellikle iptal davasının zaman aşımı süresinin dolmasından epey sonra bu tasarrufun uygulanmasıyla ortaya çıktığı gerçeğidir. (Lenaerts, Maselis and Gutman, 2014:441; Kaczorowska, 2013:447) Bu nedenle önceleri iptal davası çerçevesindeki imtiyazlı davacıların söz konusu düzenlemenin herhangi bir kısıtlamaya tabi olmaksızın zaman aşımı süresi içerisinde hukukilik denetimini iptal davası yoluyla yaptırabileceğinden hukuka aykırılık def'i ileri sürebilmesinin mümkün olmadığı yaklaşımından, (Bebr, 1966) bir düzenlemenin hukuka aykırılığının yürürlüğe girmesinden epey süre sonra, genelde düzenlemeye bağlı bir takım alt veya uygulayıcı düzenlemelerin yürürlüğe girmesi veya düzenlemenin belirli bir süre sonunda tam olarak uygulanmaya başlanması ile ortaya çıkabileceği ve bu süre zarfında da hak düşürücü sürenin geçmiş olacağından hukuka aykırılık def'inin tasarrufların hukukilik denetimi açısından imkan dahilinde olduğu yaklaşımına (Hukuk Sözcüsü Roemer'in Görüşü, Dava C-32/65 Italy v Council and Commission; Barav, 1974) evrilmiştir.

Bu doğrultuda ABAD, ABİDA 277. maddenin lafzından herhangi bir tarafın düzenlemenin dolaylı olarak hukuka aykırılı̆̆ def'ini ileri sürebileceğinin anlaşıldığı ve bir düzenlemenin hukuka aykırılığı def'ini ileri sürebilme imkanının imtiyazlı bir davacıya tanınmamasının 277. maddenin lafzına aykırılık teşkil edeceği gerekçesiyle öğretideki ikinci görüşü izlemektedir. (Dava C-442/04 Spain v Council, para. 22) Bununla birlikte ABAD, diğer yandan hukuki etkileri olan $\mathrm{AB}$ tasarruflarının süresiz olarak denetime tabi tutulmasını önlemek amaciyla hukuki belirlilik ilkesi konusundaki tutumunu korumakta, bir üye devlete kendisini muhatap alan bir Komisyon kararına 
ilişkin hukuka aykırılık def'i ileri sürebilme imkanı tanımayarak bu yargı yolunun iptal davası şartlarının dolaşılması için kullanılmasını da engellemektedir. (Dava C-156/77 Commission v Belgium, para. 22) Yani ABAD'ın yerleşik içtihadında imtiyazlı davacılara, kendilerini muhatap alan kararlara veya yönergelere ilişkin değil, (Dava C-11/00 Commission v ECB; Dava C-154/00 Commission v Greece, para. 28; Dava C-118/03 Commission v Germany, para. 7; Dava C-53/05 Commission v Portugal, para. 30) sadece tüzüklere ilişkin hukuka aykırılık def'i ileri sürebilme imkanı tanınmaktadır. (Lenaerts, Maselis and Gutman, 2014:449) Başka bir ifadeyle, kendilerini muhatap alan yönerge ve kararlara ilişkin hukuka aykırılık def'i bir alternatif yarg1 yolu yaklaşımıyla değerlendirmeye tabi tutularak kabul görmemekte, tüzüklere ilişkin olarak ise hukuka aykırılık def'i tamamlayıcı bir yaklaşımla diğer şartları karşıladığı takdirde kabul edilebilir nitelik arz etmektedir. Ancak bu içtihadın asıl gerekçesinin Lizbon öncesi hukuka aykırılık def'ini düzenleyen maddedeki tüzük kavramı mı olduğu, tasarrufun muhatap alması hasebiyle bu tasarrufların muhatapları için birel işlem mi teşkil ettiği, yoksa bu tasarrufların hukuka aykırılığı hakkında muhatapları tarafından malumat sahibi olmadıkları şeklindeki argümanı temelsiz kılması mı olduğu noktasında tam bir açıklık yoktur. Görüleceği üzere ikinci yaklaşım çerçevesinde bile hukuka aykırılık def'inin iptal davasına alternatif oluşturacak ve koşullarının dolaşılmasına imkan verecek şekilde ikinci bir denetim olasılığı tanımasına imkan tanınmamaktadır. (Sinaniotis, 2001)

Bu itibarla hukuka aykırılık def'i imtiyazsız davacılar açısından iptal davası ehliyet kısıtlılığını telafi edici mahiyet taşımakta, genel uygulaması olan tasarrufların hukuki etkilerinin ortaya çımasıyla birlikte zaman zaman denetime tabi kılınmasını sağlamaktadır. (Hukuk Sözcüsü Mancini’nin Görüşü, Dava C-204/86 Hellenic Republic v Council) İmtiyazlı davacılar açısından ise hukuka aykırılık def'i iptal davasına tamamlayıcı nitelik arz eden bir yargı yolu olarak öne çıkmaktadır. Bu çerçevede içtihatta hukuka aykırılık def'inin imtiyazlı ve imtiyazsız davacılar açısından farklılık arz etmek üzere iki asli gereği ortaya çıkmaktadır: İmtiyazlı davacılar için iptal davası açma hakkının kullanımı açısından iki aylık başvuru süresinin genel uygulama kapasitesine sahip tasarrufun hukuka aykırılığının ortaya çıkabilmesi için yeterli olmaması; imtiyazsız davacılar olarak gerçek ve tüzel kişilerin dava ehliyetinin özellikle bireysel ilgi şartı nedeniyle kısttlı yorumlanması itibariyle, bu kısıtlllığ etme adına, genel uygulama kapasitesine sahip tasarrufların arızi ve dolaylı nitelikte alternatif bir yarg1 yoluyla hukuka aykırılığının ileri sürülebilmesi. (Dava C-92/78 Simmenthal, para. 41; Bebr, 1981:193; Lenaerts, Maselis and Gutman, 2014:442)

$\mathrm{Bu}$ çerçevede gerçek ve tüzel kişiler açısından hukuka aykırılık def'i ileri sürebilme ancak iptal davası ehliyetine sahip olmadıkları tasarruflar için söz 
konusudur. Yani hukuki belirlilik açısından Divan, tasarrufa ilişkin iptal davasına başvuru süresini kaçırmış, ya tasarrufun muhatabı olan, ya tasarrufta ismi zikredilen ya da o tasarrufa bireysel ve doğrudan ilgili olabileceği açık olan kişilere bu tasarrufa karşı ikinci kez dava açma hakkı vermemekte, tasarrufların süresiz şekilde sorgulanmasına engel olmaktadır. (Dava C-178/95 Wiljo, para. 19-21; Dava C-241/01 National Farmers' Union, para. 34-35) İstisnai olarak ise, iptal davası ehliyetine dair makul şüphesi olan kişiler için (Dava T-343/02 Schintgen, para. 26) ve ciddi ve ağır sakatlıkla malul yok hükmünde işlemler (Dava C-15/85 Consorzio Cooperative d'Abruzzo, para. 10; Dava C-226/87 Commission v Hellenic Republic, para. 16) için de söz konusu olabileceğinin bilinmesi de gerekir. (Lenaerts, Maselis and Gutman, 2014: 445) $\mathrm{Bu}$ itibarla Divan, gerçek ve tüzel kişilerin iptal davası ehliyetinin olmadığ1 genel uygulanma kapasitesi olan tasarrufların uygulanmasından üye devletlerin sorumluluğunun olduğu yerlerde, uygulayıcı tasarruflara ilişkin ulusal mahkemeler önünde açılan davalarda ön karar usulü çerçevesinde söz konusu genel tasarrufların geçersizliğinin ileri sürülebilmesi imkanı ile AB organlarının sorumlu olduğu yerlerde de, dava ehliyetine sahip oldukları uygulayıcı tasarruflar aleyhine açtıkları davalarda hukuka aykırılık def'inin ileri sürülebilmesi imkanına vurgu yapmaktadır. (Dava C-294/83 Les Verts, para. 23)

\section{Hukuka Aykırılık Def'inin Hukuki Sonuçları}

ABIDA 277. maddenin en önemli amacı ilgili tarafı hukuka aykırı genel tasarrufun uygulanmasına karşı korumaktır. (Birleşik Davalar C-31/62 and C33/62 Lütticke) Hukuka aykırılık def'i prensipte yalnızca davanın taraflarını ilgilendiren ve iptal davasının aksine genel uygulamaya konu olmayan hukuki sonuçlar yaratır. Başka bir deyişle, ABİDA 277. maddede de belirtildiği üzere başarılı bir hukuka aykırılık def'inin sonucu, söz konusu genel uygulanmaya sahip düzenlemenin yalnızca davanın tarafları yönünden (inter partes) ve geleceğe dönük (ex nunc) (Bebr, 1981:217) uygulanamaz nitelikte olmasıdır. (Dava C-434/98 P Busacca, para. 26) Yani ABAD, hukuka aykırılık def'ine konu edilen tasarrufların dolaylı olarak uygulanamaz bulunmasının, yalnızca taraflar arasındaki asli dava kapsamında bağlayıcılık taşıyacağına karar vermiştir. (Dava C-434/98 P Busacca, para. 26) Bu itibarla hukuka aykırılık def'i olabildiğine bireysel ve sınırlı etkide bir yarg1 yolu teşkil etmektedir (Birleşik Davalar C-31/62 and C-33/62 Lütticke; Bebr, 1981:193) ve bu tasarruf ilkesel olarak hükümsüz kılınamaz. Bu doğrultuda hukuka aykırılık def'inin Divan tarafindan kabul edilmesi sonucunda erga omnes değil, inter partes bir etki oluşmaktadır. (Türk, 2009:213) ABAD'ın bu husustaki görüşü de hukuka aykırılık def'inin hukukun genel ilkelerine dayandığı ve ilgili düzenlemenin iptali için ABIDA 266. maddede belirlenen hak düşürücü sürenin geçmiş olması sebebiyle iptal kararı verilemeyeceği kanaatine dayanmaktadır. Bu 
itibarla hukuka aykırılık def'inin başarılı olması halinde ABAD içtihatlarıyla uyum sağlanması doğrultusunda genel düzenlemenin, sahibi organ veya kurum tarafindan ilga veya tadil edilmesi gerekmektedir. (Hukuk Sözcüsü Roemer'in Görüşü, Birleşik Davalar C-9 and C-12/60 Vloeberghs; Wathelet, Contentiuex 2014:305; Barav, 1974; Kaczorowska, 2013:447) Başarılı bir hukuka aykırılık def'inin ardından, hiçbir yasal zorunluluğu olmamasına rağmen ABAD ile çelişmek istemeyen $\mathrm{AB}$ organ ve kurumlarının, söz konusu düzenlemeyi tadil etme yönünde hareket edebileceği ve bu durumun da ileri sürücüyü iptal davas1 ile ulaşmak istediği sonuca yakın bir sonuca ulaştırabileceği de öne sürülebilir. (Kaczorowska, 2013:447)

Diğer yandan uyuşmazlık konusu düzenlemenin, düzenleyici kurum tarafından ilga veya tadil edilene kadar tasarrufun davanın tarafları dışında genel bağlayıcılığının bulunması durumunda bu yargı yolunun etkililiği de tartışmaya açık hale gelmektedir. Öyle ki, hukuka aykırılık def'i ile genel düzenlemenin iptal edilememesi, ileride benzer uyuşmazlıkların yeniden yaşanmasına sebep olabilecektir. $\mathrm{Bu}$ açıdan başarılı bir hukuka aykırılık def'inin hukuki sonucunun ABAD'ın yerleşik ön karar usulü içtihadına paralel bir şekilde erga omnes etkisinin olduğuna dair literatürde haklı yaklaşımlar bulunmaktadır. (Capdevila, 2006) Divan, AB organının tasarrufunun geçersizliğine hükmedilen ön kararın, doğrudan kendisine ön karar usulü çerçevesinde konuyu havale eden ulusal mahkemeyi muhatap almasına ve bağlamasına rağmen başka bir ulusal mahkemenin önüne gelen davalarda vereceği hükümlerde bu tasarrufu hükümsüz olarak değerlendirmesi için yeterli gerekçe oluşturduğunu belirtmiştir. (Dava C-66/80 SpA, para. 13) Ön karar usulü çerçevesinde ABAD hem yorum amaçlı ön karar başvuruları, (Dava C283/81 CILFIT) hem de geçerlilik denetimi amaçlı ön karar başvuruları üzerine verilen içtihatlarına emsal değeri kazandırmış, bu sayede ön karar usulünü, havale eden ulusal mahkemeyle kendisi arasındaki diyalog ilişkisinden, bütün ulusal mahkemeler arasındaki pluralog ilişkisine taşıyarak $\mathrm{AB}$ hukukunu bütün ulusal hukuk sistemlerinde konsolide etmiştir. (de la Mare and Donnelly, 2011:376-379) Ön karar usulü ile hukuka aykırılık def'inin en önemli ortak noktası AB tasarruflarının dolaylı yargısal denetim mekanizması olmalarıdır ve bu itibarla doğrudan yargı yollarıyla arasındaki ilişkilerde, bütün $\mathrm{AB}$ yargısal denetim sisteminin tutarlılığı ve bütünselliği açısından, olabildiğine yeknesak hükümlere tabi olmaları gerekir. Dolaylı yargı yolları olarak hukuka aykırılık def'i ile ön karar usulüne yönelik içtihadın genelde bu yeknesaklığ 1 dikkate alındığında, hukuka aykırılık def'i sonucunda verilen AB tasarruflarının hukuka aykırılığına dair kararlarının aynı eksende davanın taraflarını aşar mahiyette etkisinin olduğunu savunmak gerekecektir. Zaten hukuka aykırılığ 1 tespit edilmiş bir tasarrufun uygulanmasının hukuki kesinlik ilkesini zedeler nitelik taşıyacak olduğunun ve bu tasarrufun uygulanmasının hukukilik ilkesini zedeleyeceğinin bilinmesi gerekir. Ayrıca kanaatimizce zaten hiçbir yasal 
zorunlulukları olmamasına rağmen tasarrufun sahibi $\mathrm{AB}$ organ veya kurumun, aslen ABAD içtihatlarıyla uyum sağlanması doğrultusunda bir mükellefiyet algısıyla söz konusu tasarrufu ilga veya tadil etmesine dair gereklilik kanaati, aslen başarılı hukuka aykırılık def'ilerinin inter partes etkiyi aşar nitelik taşıdığının zımnen kabulünün bir göstergesi olduğu da açıktır.

\section{Genel Değerlendirme}

ABIDA 277. maddenin lafzındaki birtakım eksikliklerden kaynaklanan her ileri süren tarafa, imtiyazlı veya imtiyazsız olmasına bakılmaksızın, yeknesak uygulanmasını sağlayamayacak boyutlarının fiiliyatta söz konusu olabileceği bilinmelidir. Bu açıdan imtiyazsız davacılar olarak gerçek ve tüzel kişiler için alternatif bir yargı yolu olarak kurgulanırken, imtiyazlı davacılar için ise tamamlayıcı bir yargı yolu olma özelliği öne çıkmaktadır. Bu itibarla, iptal davasının imtiyazsız davacıları için bir alternatif, imtiyazlı davacıları içinse bir tamamlayıcı yargı yolu arz eden hukuka aykırılık def' $i$, AB yargısal sisteminin doğrudan ve dolaylı yargı yollarıyla etkili hukuki/yargısal koruma sağlamasının tam niteliği açısından önemli bir dolaylı yargı yolu teşkil etmektedir. (Dava C294/83 Les Verts, para. 23; Dava C-50/00 P UPA, para. 40; Dava T-122/05 Benkö, para. 49)

Hukuka aykırılık def'i müstakil ve asli bir yarg1 yolu olmayıp, Andlaşma'nın başka bir hükmüne istinaden açılan başka bir davada ileri sürülebilecek bağlı ve dolaylı bir yargı yoludur. Bu nedenle, öğretide asalak yarg1 yolu olarak dahi tanımlanmaktadır. (Chalmers, Davies and Monti, 2010:430) ABAD'ın yerleşik içtihadı, bağlı karakteri nedeniyle ana davanın kabul edilemez bulunduğu davalarda hukuka aykırılık def'inin de kabul edilemeyeceği şeklindedir. (Dava C-64/93 Donatab, para. 20; Birleşik Davalar T-54/00 and T-73/00 Federación de Cofradias de Pescadores de Guipúzcoa, para. 82; Dava T-369/03 Arizona Chemical, para 129) Bu itibarla etkili hukuki korunma açısından ilk dava ehliyeti önem arz etmektedir ve bu durum gerçek ve tüzel kişiler tarafından hukuki korunmanın etkililiğini belirleyebilecek bir durumdur. Özellikle, ABIDA 277. madde genel olarak ABIDA 263. maddede düzenlenen iptal davasına atıf yapmakta ve temelini bu düzenlemeden almaktadır. Bu doğrultuda, uygulamada gerçek ve tüzel kişilerin iptal davası ehliyetleri açısından mustarip olduğu birtakım sorunların hukuka aykırılık def'ine de sirayet etmesi itibariyle etkilenebilecekleri göz önünde bulundurulmalıdır. Ancak yine de, en azından gerçek ve tüzel kişiler açısından alternatif yargı yolları olmaları hasebiyle, iptal davası ehliyeti ile hukuka aykırılık def'i ileri sürebilme hakkı arasında da ters bir orantının mevcut olacağ 1 gözden kaçırılmamalıdır.

Hukuka aykırılık def' inin, imtiyazlı ve imtiyazsız davacılara tanınması hem hukuki çareler ve yargı yollarının tamlığının teyidi ile davacılara zamanaşımı 
süresinde iptal davası açmadaki ihmalkarlıklarını ödüllendirme (Barav, 1974) ve davacılara diğer yargı yollarının başvuru şartlarının dolaşılması imkanını verecek mahiyette ikinci bir hak verilmesi arasında, yani gerek telafi gerekse tamamlayıcı olma arasında, gerçek amacının belirlenmesi açısından hassas bir denge üzerine kurulması sağlanmalıdır. Bu denge, dolayısıyla, yargı yollarının özerkliği ve yargısal denetim sisteminin bütünselliği ve insicamı içerisinde birbiriyle münasebeti ve sistematik yorumlanması çerçevesinde hukuka uygunluk karinesi, hukuki kesinlik, hukukilik denetimi, adaletin reddinin önlenmesi ve etkili yargısal korunmadan müteşekkil ilkeler arasında da bir denge sağlanmasını ifade edecektir. Yani bu denge aynı zamanda, AB yargısal denetim sisteminin asli ve tali yargı yolları arasında da sağlanacak ve dolayısıyla onların varlık sebebi, işlevselliği ve aralarındaki irtibat açısından da belirleyici olacak bir dengedir. ABİDA 277. madde lafzının iç tutarsızlığının bu dengeyi sağlamakta ne kadar büyük bir badire teşkil ettiği de açıktır. Bu açıdan lafzi yorum ile ABAD'in yargısal aktivizminin temel metodu olan amaçsal (teleolojik) yorum arasında da hukuka aykırılık def'inin temel amacı ekseninde ve söz konusu ilkeler 1şığında doğası itibariyle büyük zorluk taşıyan bir yaklaşımın sergilenmesi gerekmektedir. $\mathrm{Bu}$ nedenle bir yandan imtiyazsız davacılar olarak gerçek ve tüzel kişilerin iptal davasının özellikle bireysel ilgi şartına dayanan kısıtlı dava ehliyetine yönelik yaklaşımların hukuka aykırılık def'ine taşınarak aleyhlerine adaletsizlik durumundan, diğer yandan da iptal davası imtiyazlı davacıları olarak organ ve üye devletlerin de imtiyazlı durumunun hukuka aykırılık def' ine taşınarak imtiyazlı durumlarının başka bir yarg1 yolu içerisinde sürdürülmesinden kaynaklı lehlerine adaletsizlik durumundan kaçınılması gerekmektedir. ABAD içtihadında görüleceği ve yukarıda da sıklıkla belirtildiği üzere imtiyazlı ve imtiyazsız davacılara hukuka aykırılık def'i hakkı farklı gerekçeler üzerine inşa edilmektedir. İmtiyazsız davacılar için bu hak, dava ehliyetleri olmadığ 1 için aleyhlerine iptal davası açamadıkları genel uygulama tasarruflarına karşı yargısal korunma hakkı tanınması şeklinde ortaya çıkarken, imtiyazlı davacılar açısından da gerek hukuka aykırılığın ortaya çıkması için iptal davasına başvuru süresi için tanınan 2 aylık sürenin yeterli olmaması, gerekse hukuka aykırılığın ancak uygulayıcı tasarruflar marifetiyle ortaya çıkmış olması itibariyle tamamlayıcı nitelikte bir yargısal korunma hakkı olarak ortaya çıkmaktadır. Bu itibarla gerçek ve tüzel kişiler açısından da iptal davası ehliyeti dava açmış olsalardı bulunabilecek konumdaki tasarruflara ilişkin, aynen imtiyazlı davacılara olanak tanındığ şekilde, hukuka aykırılığın ortaya çıkmasının zaman alması gibi makul bir gerekçeyle ama istisnai durumlara hasredilmek üzere, hukuka aykırılık def' $i$ imkanının tanınması içtihadın tutarlılı̆̆ı ve etkili yargısal korunmanın temini adına önem arz etmektedir. Aksine bir tutumun, imtiyazlı davacılara tanınan bu hakkın imtiyazsız davacılara tanınmamasının, ihtiyaten dava açma olanakları imtiyazlı davacılara göre epey kısıtlı olan ve tasarrufların hukukiliğinin 
denetimini kişisel çıkarlarını aşar mahiyette kamusal bir amaçla üstlenmeleri de beklenmeyecek olan imtiyazsız davacılar aleyhine bir adaletsizlik doğuracağ açıktır.

Diğer yandan, dolaylı yargı yolları arasındaki ilişkiye istinaden içtihattaki yeknesaklık boyutu itibariyle, hukuka aykırılık def'inin hukuki sonuçlarının ön karar usulüyle (Dava C-66/80 $S p A$, para. 13) paralel şekilde yoruma tabi tutulması suretiyle inter partes boyutu aşarak erga omnes niteliğe kavuşturulamaması bu yargı yolunun yargısal korunmadaki etkililik düzeyi açısından belirleyici bir nitelik taşımaya devam edecektir. Bu açıdan ABİDA 277. maddenin lafzının hukuka aykırılık def'inin etkili yargısal korunma ilkesi açısından $\mathrm{AB}$ yargısına yargısal aktivizm sergileyebilmesi adına ne kadar olanak taşıdığı da ayrı bir araştırma konusudur.

$\mathrm{Bu}$ çerçevede $\mathrm{AB}$ hukukunun uygulanması yükünün çoğunun üye devletlerin omuzlarında olduğu, $\mathrm{AB}$ organları tarafından uygulanmasının istisna teşkil ettiği nazarı dikkate alınırsa, hukuka aykırılık def'inin ön karar usulüne nazaran gerçek ve tüzel kişilerin yargısal korunmasına yönelik işlevinin yine de tali kalacağı zaten açıktır. Bununla birlikte, iptal davası çerçevesinde dava ehliyetlerinin kısıtlı yorumlanması nedeniyle ana yargısal denetim kulvarını hala ön karar usulü teşkil etse de, $\mathrm{AB}$ organlarının uygulayıcı tasarruf yaptığı durumlarda hukuka aykırılık def'inin, yargısal denetim sisteminin doğrudan ve dolaylı yollarıyla birlikte tamlığı ve dolayısıyla yargısal korunmanın boşluksuz etkililiğinin sağlanması açısından tali de olsa büyük bir işlevinin bulunduğu yadsinamaz. 


\section{Kaynakça:}

Barav, A. (1974) "The Exception of Illegality in Community Law: A Critical Analysis", 11 CMLRev. 366.

Bebr, G. (1966) "Judicial Remedy of Private Parties against Normative Acts of the European Communities: The Role of the Exception of Illegality" 4 CMLRev 7.

Bebr, G. (1981) Development of Judicial Control of the European Communities, (Martinus Nijhoff Publishers, The Hague, Boston, London).

Birleşik Davalar C-140, 146, 221 and C-226/82 Walzstahl-Vereinigung and Thyssen Aktiengesellschaft v Commission, EU:C:1984:66.

Birleşik Davalar C-189/02 P, C-202/02 P, C-205/02 P to C-208/02 P and C-213/02 P Dansk Rørindustri A/S and others, EU:C:2005:408.

Birleşik Davalar C-31 and 33/62 Milchwerke Heinz Wohrmann \& Sohn KG and Alfons Lütticke GmbH v Commission, EU:C:1962:49.

Birleşik Davalar C-87, C-130/77, C-22/83, C-9 and C-10/84 Salerno and others v Commission and Council, EU:C:1985:318.

Birleşik Davalar C-90/63 and 91/63 Commission v Luxembourg and Belgium, EU:C:1964:80.

Birleşik Davalar F-69/07 and F-60/08 O v Commission, EU:F:2009:128.

Birleşik Davalar T-134/03 and T-135/03 Common Market Fertilizers SA v Commission, EU:T:2005:339.

Birleşik Davalar T-222/99, T-327/99 and T-329/99 Jean-Claude Martinez and others v Commission, EU:T:2001:242.

Birleşik Davalar T-54/00 and T-73/00 Federación de Cofradías de Pescadores de Guipuzcoa and Others v Council, EU:T:2001:224.

Birleşik Davalar T-6/92 and T-52/92 Reinarz v Commission, EU:T:1993:89.

Birleşik Davalar T-93/00 and T-46/01 Alessandrini and Others v Commission, EU:T:2003:110.

Capdevila, C. M. (2006) "The Action for Annulment, the Preliminary Reference on Validity and the Plea of Illegality: Complementary or Alternative Means?", 25 Yearbook of European Law 451.

Chalmers, D., G.Davies and G. Monti, (2010), European Union Law: Cases and Materials, (Cambridge University Press, Cambridge).

Craig, P. and G. De Búrca, (2011) EU Law: Text, Cases, and Material, Fifth Edition, (Oxford University Press, Oxford).

Dava 262/80 Kirsten Andersen and others v European Parliament, EU:C:1984:18. 
Dava C-11/00 Commission v ECB, EU:C:2003:395.

Dava C-116/82 Commission v Germany, EU:C:1986:322.

Dava C-118/03 Commission des Communautés européennes contre République fédérale d'Allemagne, EU:C:2004:458.

Dava C-119/05 Ministero dell'Industria, del Commercio e dell'Artigianato v Lucchini SpA, EU:C:2007:434.

Dava C-14/59 Société des fonderies de Pont-à-Mousson v High Authority of the European Coal and Steel Community, EU:C:1959:31.

Dava C-15/85 Consorzio Cooperative d'Abruzzo v Commission, EU:C:1987:111.

Dava C-154/00 Commission v Greece, EU:C:2002:254.

Dava C-156/77 Commission v Belgium, EU:C:1978:180.

Dava C-174/99 P European Parliament v Pierre Richard, EU:C:2000:412.

Dava C-178/95 Wiljo NV v Belgische Staat, EU:C:1997:46.

Dava C-183/91 Commission v Greece, EU:C:1993:233.

Dava C-188/92 TWD Textilwerke Deggendorf GmbH v Bundesrepublik Deutschland, EU:C:1994:90.

Dava C-20/71 Sabbatini v Parliament, EU:C:1972:48.

Dava C-226/87 Commission v Greece, EU:C:1988:354.

Dava C-239/99 Nachi Europe GmbH v Hauptzollamt Krefeld, EU:C:2001:101.

Dava C-241/01 National Farmers' Union v Secrétariat général du gouvernement, EU:C:2002:604.

Dava C-25/62 Plaumann \& Co. v Commission of the European Economic Community, EU:C:1963:17.

Dava C-283/81 Srl CILFIT and Lanificio di Gavardo SpA v Ministry of Health, EU:C:1982:335.

Dava C-294/83 Parti écologiste "Les Verts" v European Parliament, EU:C:1986:166.

Dava C-314/85 Foto-Frost v Hauptzollamt Lübeck-Ost, EU:C:1987:452.

Dava C-32/65 Italy v Council and Commission, EU:C:1966:42.

Dava C-322/88 Grimaldi v Fonds des maladies professionnelle, EU:C:1989:646.

Dava C-368/05 P Polyelectrolyte Producers Group v Council and Commission, EU:C:2006:771.

Dava C-404/00 Commission v Spain, EU:C:2003:373.

Dava C-404/97 Commission v Portugal, EU:C:2000:345. 
Dava C-434/98 P Council v Silvio Busacca and Others and Court of Auditors, EU:C:2000:546.

Dava C-44/65 Hessische Knappschaft v Maison Singer et fils, EU:C:1965:122.

Dava C-441/05 Roquette Frères v Ministre de l'Agriculture, de l'Alimentation, de la Pêche et de la Ruralité, EU:C:2007:150.

Dava C-442/04 Spain v Council, EU:C:2008:276.

Dava C-443/05 P Common Market Fertilizers SA v Commission, EU:C:2007:511.

Dava C-475/01 Commission v Greece, EU:C:2004:585.

Dava C-50/00 P Unión de Pequeños Agricultores UPA, EU:C:2002:462.

Dava C-53/05 Commission v Portugal, EU:C:2006:448.

Dava C-64/93 Donatab v Commission, EU:C:1993:266.

Dava C-66/80 SpA International Chemical Corporation v Amministrazione delle finanze dello Stato, EU:C:1981:102.

Dava C-69/89 Nakajima v Council, EU:C:1991:186.

Dava C-70/87 Fediol v Commission, EU:C:1989:254.

Dava C-74/91 Commission v Germany, EU:C:1992:409.

Dava C-86/03 Hellenic Republic v Commission, EU:C:2005:769.

Dava C-91/05 Commission v Council, EU:C:2008:288.

Dava C-92/78 SpA Simmenthal v Commission, EU:C:1979:53.

Dava T-120/99 Christina Kik v Office for Harmonisation in the Internal Market (Trade Marks and Designs) (OHIM), EU:T:2001:189.

Dava T-122/05 Robert Benkö and Others v Commission, EU:T:2006:262.

Dava T-135/05 Franco Campoli v Commission, EU:T:2006:366.

Dava T-140/12 Teva Pharma BV and Teva Pharmaceuticals Europe BV v European Medicines Agency (EMA), EU:T:2015:41.

Dava T-146/96 De Abreu v Court of Justice, EU:T:1998:50.

Dava T-271/04 Citymo SA v Commission, EU:T:2007:128.

Dava T-343/02 Roland Schintgen v Commission des Communautés européennes, EU:T:2004:111.

Dava T-369/03 Arizona Chemical BV and Others v Commission, EU:T:2005:458.

Dava T-373/04 Éric Mathias Fries Guggenheim v European Centre for the Development of Vocational Training (Cedefop), EU:T:2006:224.

Dava T-376/10 Mamoli Robinetteria SpA v Commission européenne, EU:T:2013:442. 
Dava T-411/06 Sogelma - Societá generale lavori manutenzioni appalti Srl v European Agency for Reconstruction (EAR), EU:T:2008:419.

Dava T-455/16 P Elia Fernández González v Commission européenne, EU:T:2017:169.

Dava T-58/01 Solvay SA v Commission, EU:T:2009:520.

Dava T-64/02 Dr Hans Heubach GmbH \& Co. KG v Commission, EU:T:2005:431.

Dava T-764/16 Jörn Paulini v European Central Bank, EU:T:2018:101.

Dava T-787/14 P European Central Bank v Maria Concetta Cerafogli, EU:T:2016:633.

Dava T-788/16 Dominique De Geoffroy v Parlement européen, EU:T:2018:534.

de la Mare, T. and C. Donnelly, "Preliminary Rulings and EU Legal Integration: Evolution and Stasis" in P. Craig and G. de Búrca (2011), The Evolution of EU Law, (Oxford University Press, Oxford).

Hukuk Sözcüsü Jacobs'ın Görüşü, Dava C-11/00 Commission v ECB, EU:C:2002:556.

Hukuk Sözcüsü Lenz'in Görüşü, Dava C-13/83 Parliament v Council, EU:C:1985:53.

Hukuk Sözcüsü Mancini'nin Görüşü, Dava C-204/86 Hellenic Republic v Council, EU:C:1988:259.

Hukuk Sözcüsü Roemer'in Görüşü, Birleşik Davalar C-9 and C-12/60 Société commerciale Antoine Vloeberghs SA v High Authority of the European Coal and Steel Community, EU:C:1961:6

Hukuk Sözcüsü Roemer'in Görüşü, Dava C-32/65 Italy v Council and Commission, EU:C:1966:14.

Hukuk Sözcüsü Slynn'ın Görüşü, Dava C-181/85 France v Commission EU:C:1986:491.

Kaczorowska, A. (2013) European Union Law, Third Edition, (Routledge, Abingdon).

Lenaerts, K., I. Maselis and K. Gutman (2015) EU Procedural Law, (Oxford University Press, Oxford).

Schermers H. G. and D. F. Waelbroeck, (2001) Judicial Protection in the European Union, (Kluwer Law International, The Hague, London, New York).

Shaw, J. (1993) Law of the European Union, (Macmillan Law Masters).

Sinaniotis, D. (2001) "The Plea of Illegality in EC Law" 7 European Public Law 103-125. 
Türk, A. and N. Xanthoulis, (2019) "Legal accountability of European Central Bank in bank supervision: A Case Study in Conceptualising the Legal Effects of Union Aacts" 26/1 Maastricht Journal of European and Comparative Law 151.

Türk, A. H. (2009) Judicial Review in EU Law, (Edward Elgar Publishing, Cornwall).

Vogt, M. (2006) "Indirect Judicial Protection in EC Law: The Case of the Plea of Illegality" 31 ELRev 364.

Wathelet, M., (2014) Contentiuex Européen, (Larcier, Bruxelles).

Xanthoulis, N. (2019) "Administrative Factual Conduct: Legal Effects and Judicial Control in EU Law", 12/1 Review of European Administrative Law 39-73. 